\title{
The diversity of fisheries based livelihoods in the Berau Delta, East Kalimantan
}

\author{
BAMBANG INDRATNO GUNAWAN
}

\begin{abstract}
Fisheries based livelihoods in the Berau Delta are diverse. The everyday life of small-scale fishers shows that gear diversification, changing fishing gear over a lifetime and practical knowledge to access good fishing grounds in the rich coastal waters are the main livelihood strategies developed by fishers. Fishing practices in the coastal frontier of Berau are influenced by the Bugis habitus of patronage networks between the punggawa and the dependent fishers. An essential element in the decision making of fishers is their embeddedness in political-economic patronage networks as the result of values, interests and knowledge contestations. Livelihood trajectories of different fishers from various classes confirm that as social actors, whether rich or poor, they have the agency to search for better livelihoods.
\end{abstract}

KEYWORDS

Fisheries based livelihoods; livelihood strategies; political-economic patronage; punggawa; agency; Berau Delta.

\section{INTRODUCTION $^{1}$}

This article is about the everyday life of fishers living in the coastal frontier of the Berau Delta in northeastern Kalimantan, Indonesia. Fishery is the major source of income and plays a very important role in the lives of the fishers in the coastal villages of the delta. The villages of Kasai and Teluk Semanting are

$1 \quad$ I would like to thank Leontine Visser for her comments on an earlier version of this paper. This paper was derived from Chapter III of my PhD thesis Shrimp fisheries and aquaculture; Making a living in the coastal frontier of Berau, Indonesia, defended on 2 October 2012 at Wageningen University (Netherlands). The online publication of this thesis can be found at http://edepot. wur.nl/231418.

Bambang Indratno Gunawan is Associate Professor at the Department of Social and Economics of Fisheries, Faculty of Fisheries and Marine Science Mulawarman University, Samarinda. He obtained a PhD from Rural Development Sociology Group of Wageningen University (WUR), the Netherlands. His scientific interests are livelihoods of small-scale fisheries and aquaculture and social process of coastal development. Bambang Indratno Gunawan may be contacted at: bambanggunawan1970@gmail.com

(C) 2016 Faculty of Humanities, University of Indonesia

BAMBANG INDRATNO GUNAWAN | DOI: 10.17510/wacana.v17i1.429 
well known for their rich resources, especially shrimps and fishes.

It is important to know the formal definition of fisheries, which defines by law that includes all activities related to management and appropriation of fish resources and their environment ranging from pre-production, production, processing up to marketing, which together form the fishery system. In addition, capture fishery (perikanan tangkap) is explained as an activity that aims to catch fish in marine waters (as opposed to ponds) using gears or any means, including activities that use a boat to load, carry, store, freeze, handle, process, and/or preserve (Law 31/2004 concerning Fisheries, Article 1, own translation).

Aquaculture is not part of the fisheries system, but the Ministry of Fisheries and Marine Affairs of Indonesia captures both domains. Fish and shrimp production in Berau consists of capture fishery and aquaculture (perikanan budidaya). Capture fishery refers to marine capture fishery (penangkapan di laut) and inland fishery (penangkapan di perairan umum) while aquaculture includes mariculture (budidaya laut/pantai), brackish water pond or shrimp pond culture (tambak), freshwater pond culture (kolam), and fish cage culture (karamba).

A picture of the fisheries production in the district of Berau over the years as compared to the whole province of East Kalimantan is presented in Table 1. In 2010 marine fisheries in Berau shared 13.7\% of the provincial level. Time series data show that the contribution of marine fisheries production in Berau compared to the province grew by $14.4 \%$ on average per year in the period 1999 to 2010. In the same period, the growth of Berau's marine fisheries production was calculated on average at $4.1 \%$ per year.

Shrimp fishery in Berau started in 1993 with the main target being white shrimp. At that time, captured shrimp production contributed $5 \%$ to the total marine fisheries production. While, tiger shrimp fishery was first recorded 6 years later and produced 18.3 tons. Data on fishery production in 2010 states tiger and white shrimp fisheries contributed around $0.6 \%$ and $4.6 \%$ to the total marine fisheries production in Berau district respectively.

In the initial fieldwork stage, I found that most fishers in the village use trammel net or gondrong. Official data from 2009 shows that in Kasai, a village of 472 (2007) households, 217 households or $46 \%$ was dependent on fisheries. I have also included crab fishers, because research shows that crab fishers in Kasai also catch shrimp. Most fishers have more than one gear. For example, trammel net or gill net fishers also use rakkang, the local name for crab trap fishery and it uses when fishers catch less shrimp, as part of their fisheries strategy. In Teluk Semanting there were 36 gill netters in this village. Later on the punggawa (entrepreneurs) in this village developed a relationship in fish transactions with fishers from outside.

In Kasai there are five main fishing gear types namely trammel net or gondrong, mini trawl (trauler), long line (rawai), gill net (pukat), and crab cage (rakkang). Trammel net is used to catch udang putih ${ }^{2}$ (white shrimp, Penaeus indicus), trawl for udang windu (tiger shrimp, Panaeus monodon) and udang bintik (Metapenaeus monoceros), long line for ikan hiu (shark), kerapu (grouper), and

2 Local people in Kasai recognize white shrimp as udang putih or udang ekspor. 
ikan kakap (snapper, barramundi), gill net for ikan putih (big eye trevally, Caranx sexfasciatus) and ikan bawal (silver pomfret, Pampus argenteus), and rakkang for kepiting bakau (mud crab, Scylla serrata).

\begin{tabular}{|l|l|l|c|c|c|c|}
\hline \multirow{2}{*}{$\begin{array}{l}\text { Admin } \\
\text { levels }\end{array}$} & \multicolumn{7}{|c|}{ Year } \\
\cline { 2 - 7 } & \multicolumn{1}{|c|}{1999} & \multicolumn{1}{|c|}{2000} & \multicolumn{1}{|c|}{2001} & \multicolumn{1}{c|}{2002} & \multicolumn{1}{c|}{2003} & 2004 \\
\hline Indonesia & $\mathrm{nd}^{*}$ & $\mathrm{nd}^{*}$ & $3,966,480$ & $4,073,506$ & $4,383,103$ & $4,320,241$ \\
\hline East Kal & 78,934 & 71,937 & 82,715 & 84,089 & 87,803 & 93,511 \\
\hline Berau & 9,822 & 10,507 & 11,193 & 11,989 & 12,629 & 13,268 \\
\hline
\end{tabular}

\begin{tabular}{|l|c|c|c|c|c|c|}
\hline \multirow{2}{*}{$\begin{array}{l}\text { Admin } \\
\text { levels }\end{array}$} & \multicolumn{1}{|c|}{ Year } \\
\cline { 2 - 7 } & 2005 & \multicolumn{1}{|c|}{2006} & \multicolumn{1}{|c|}{2007} & \multicolumn{1}{c|}{2008} & 2009 & 2010 \\
\hline Indonesia & $4,408,499$ & $4,512,191$ & $4,734,280$ & $4,701,933$ & $4,812,235$ & $5,058,260$ \\
\hline East Kal & 99,692 & 90,825 & 95,740 & 92,176 & 94,938 & 111,703 \\
\hline Berau & 13,561 & 13,854 & 14,136 & 14,631 & 15,056 & 15,327 \\
\hline
\end{tabular}

*nd= no data

Table 1. Marine fisheries production (tons) in Indonesia, East Kalimantan, and Berau. Source: MMAF (2006, 2009, 2010a,b, 2011), BPS Berau (2008, 2011), DKP Berau (1999-2011).

The shrimp caught by fishers from Kasai are bought by the shrimp trader named $\mathrm{CV}^{3}$ Surya Indah Perkasa (SIP) based in the district capital of Tanjung Redeb, who distinguishes different shrimps, namely tiger, white, pink-T, yellow, and brown shrimps, and uses different prices depending upon shrimp sizes. The scientific names of traded shrimps in Tanjung Redeb is shown in Table 2.

\begin{tabular}{ll}
\hline Trade shrimp names & Scientific shrimp names \\
\hline Tiger & Penaeus monodon \\
White & Penaeus indicus \\
Pink-T & Metapenaeus affinis \\
Yellow & Metapenaeus brevicornis \\
Brown & Penaeus semisulcatus \\
\hline
\end{tabular}

Table 2. Scientific names for traded shrimps in Tanjung Redeb. Source: CV Surya Indah Perkasa, Tanjung Redeb (2009).

Most fishers in Kasai are Bugis. Based on my data survey from 2009, 51 out of 97 of the fishers are of Bugis origin. Originally, their homeland is the south-western peninsula of Sulawesi Island and they belong to the great family

3 From Dutch commanditaire vennootschap 'limited partnership'. 
of the Austronesian people (Pelras 1996: 1). Outside Sulawesi, the different kingdoms are not well distinguished, and often people just call migrants from southern Sulawesi Bugis, Bugis-Makassar, or BBM (Bugis-Buton-Makasar), although they may also include migrants from Bone, Wajo, and even include the very different sea-dwelling Bajo or Bajau (Lowe 2003).

The Bugis are known by their neighbours for their fierce character and sense of honour, which sometimes result in violence; and yet they are among the most hospitable and amicable peoples and the most faithful in their friendships. The cohesion of their society is based largely on the existence of a system of pervasive and interlocking clienteles; and yet most of them have a strong sense of their individuality. Bugis society is one of the most complex and apparently rigidly hierarchical of any in Insulindia; and yet competition for office or wealth ranks high among their motivations (Pelras 1996: 3).

Migrations of Bugis people from their home land in South Sulawesi to East Kalimantan can be traced back from the fact that a small settlement of Wajo traders was already established in the early eighteenth century in Pasir (Levang 2002: 4). He noted that the first settlements in the Mahakam Delta of East Kalimantan were in Pemangkaran village which were inhabited by Bajo and Bugis fishers. This village was probably established by Bajo originating from Muara Telake (Pasir) around the end of the nineteenth century. But the first important migration wave was initiated by the conquest of Bone by the Dutch in 1905. Nowadays in fact, Bugis people live along the coast of East Kalimantan and mostly engage with fishing and aquaculture based livelihoods.

This study was conducted in the coastal area of the province of East Kalimantan in the Berau district where fishing is the main livelihood generated by coastal people. The study area is located in three villages namely Kasai and Teluk Semanting (Figure 1). The district is situated in the northern part of the province and geographically located between latitudes $01^{0} \mathrm{~N}$ to $02^{0} 33^{\prime}$ $\mathrm{N}$ and longitudes $116^{\circ} \mathrm{E}$ to $119^{\circ} \mathrm{E}$ and has a total area of $34,127 \mathrm{~km}^{2}$ of which the Berau coastal and marine waters cover 35.7\% (Wiryawan et al. 2005; BPS Berau 2011).

Between 2008 and 2010, I periodically lived in the research villages of Kasai and Teluk Semaning in the Berau Delta where I studied how different social actors make a living from fisheries. Thus I witnessed how different values, interests and knowledge were shared and contested in this resource-rich coastal area. Just like the Mahakam delta a decade ago, currently the Berau Delta can be regarded as an economic and social frontier area as its marine wealth attracts both wealthy entrepreneurs or punggawa (Timmer 2011: 706) and poorer fishers, mainly from Sulawesi. According to Agergaard et al. (2010: 3-4) the term of frontier is not only used to denote areas that are advancing in a spatial sense, but also includes areas that are experiencing social and economic fluidity due to new opportunities. Based on this definition the observed dynamics of fisheries and pond based livelihood opportunities in coastal Berau clearly make it into a frontier area. 


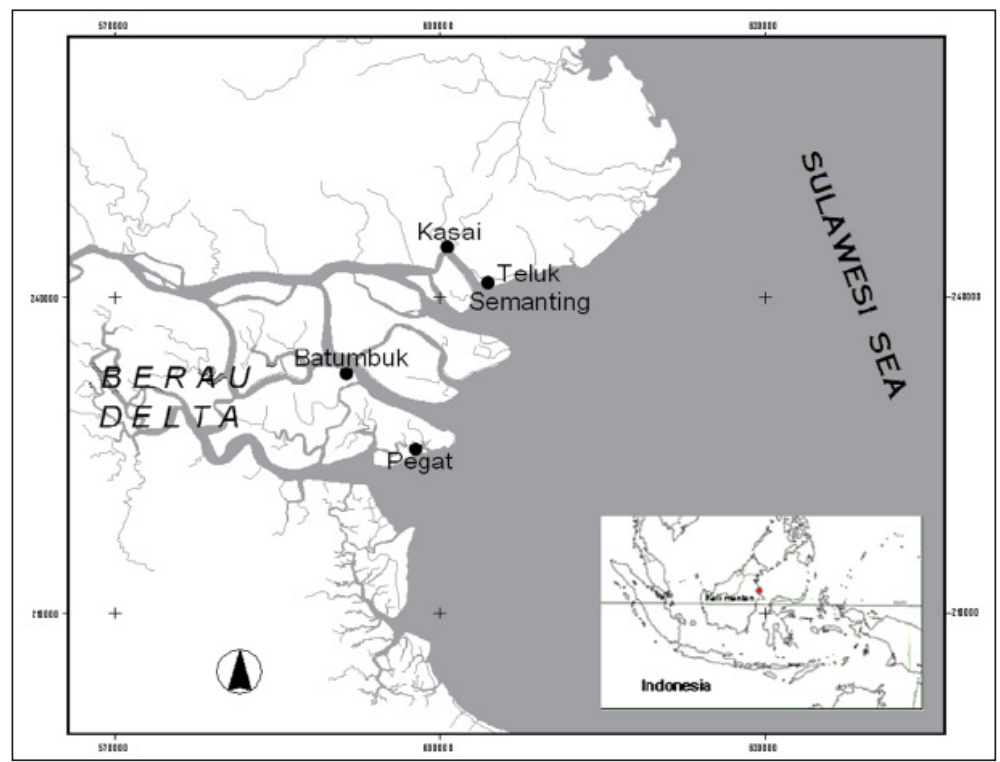

Figure 1. Map of the villages of Kasai and Teluk Semanting in the Berau Delta (by the author).

Kasai village is the largest, has a considerable terrestrial space, and the majority of its inhabitants are fishers as well as in Teluk Semanting. The total area of Kasai is 40.97 square kilometres while Teluk Semanting covers almost 100 square kilometres. The demographic situation of the research villages is as follows. The population of Kasai village was calculated 2,126 people and 428 households, while Teluk Semanting is small and counts only 192 people and 50 households as shown in Table 3 below.

\begin{tabular}{|l|l|l|l|l|}
\hline Village & Male & Female & Total & Household \\
\hline Kasai & 1,110 & 1,016 & 2,126 & 428 \\
\hline $\begin{array}{l}\text { Teluk } \\
\text { Semanting }\end{array}$ & 96 & 96 & 192 & 50 \\
\hline
\end{tabular}

Table 3. Population and household numbers in the research villages. Source: BPS Berau (2011).

The district government of Berau launched the Berau Marine Protected Area (MPA) in 2005 through the District Head Decree no. 31/2005 (see Figure 2). The MPA covers an area of 1,222,988 hectares and is part of the Coral Triangle. It is located between latitudes $02^{\circ} 49^{\prime} 42.6^{\prime \prime} \mathrm{N}$ to $01^{\circ} 02^{\prime} 0.06^{\prime \prime} \mathrm{N}$ and longitudes $117^{\circ} 59^{\prime} 17.16^{\prime \prime} \mathrm{E}$ to $119^{\circ} 02^{\prime} 50.30^{\prime \prime} \mathrm{E}$. The MPA is bordered by the Pulau Panjang Reef, Karangtigau cape, and Baliktaba Reef to the north, by the Kalimantan mainland to the west, Makasar Strait to the east, and by Cape Mangkalihat in the south (Wiryawan et al. 2005). 


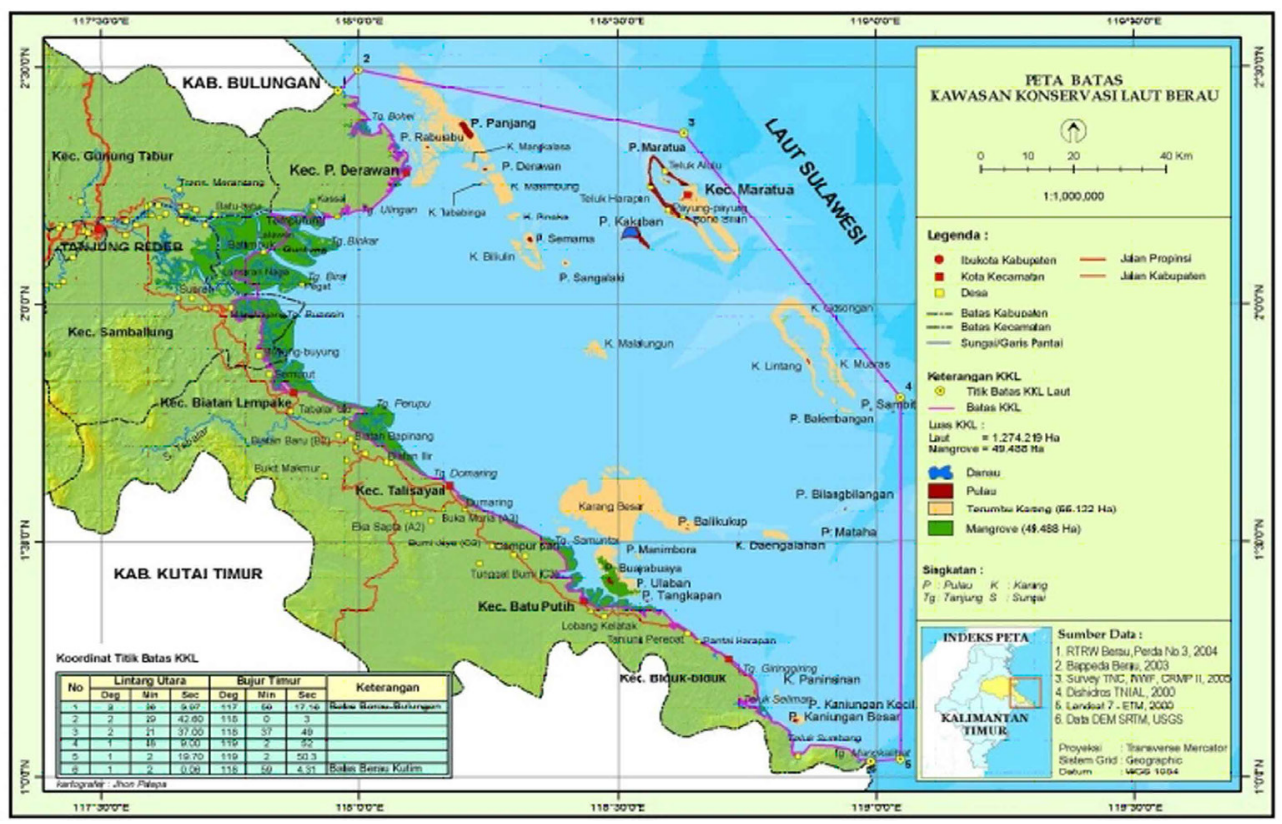

Figure 2. Map of the boundaries of the Berau MPA. Source: District Head Regulation No. 31/2005.

The coastal area of Berau has a very rich marine life with an abundance of fish species, crustaceans, coral reefs, mangroves, and sea grass fields in the estuarine ecosystem and the small islands ecosystem. The corals reefs system of the Berau MPA consists of six main islands namely Pasir Panjang, Derawan, Semama, Sangalaki, Kakaban, and Maratua. The reefs can be distinguished by their fringing reefs, barrier reefs, and atolls (Wiryawan et al. 2005).

The research is designed so as to combine both qualitative and quantitative methods. It is a bottom-up study of the everyday ways of making a living by the individual and institutional actors who are involved in fisheries and pond aquaculture at multiple social scales, using actor and the actor-oriented approach (Long 2001). Ethnographic, qualitative, and quantitative research methods are applied, including a household survey. The units of analysis vary from individuals to households and institutions. The field research was designed to use qualitative methods and techniques like in-depth interviews with key informants and focus group discussion to obtain the necessary knowledge to formulate appropriate questions for the household survey.

From January 2008 onwards I first carried out a qualitative study to collect evidence from different social actors with various perspectives in relation to fisheries and pond based livelihoods. Cases from individual fishers were gathered to answer the "how" and "why" questions, with the aim of investigating a contemporary phenomenon within its real-life context (Yin 2003). Analysis of life histories is used in this study to gain insight in how multiple livelihood trajectories happen simultaneously in the different settings of the actors (Ontita 2007). 
Data for the excerpts of case studies and life histories presented throughout this article come from participant observation, unstructured in-depth interviews and semi-structured interviews with key informants from all categories of actors including the different classes of fishers based on the use of gear, fish collectors, village heads, and punggawa.

The household survey in Kasai $(\mathrm{N}=97)$ was done between March and April 2009 while a Focus Group Discussion (FGD) was conducted in the same village on 13 February 2009 to which 14 fishers with different gear uses were invited, together with two fisheries field officers. In the survey, a proportionate stratified random sampling was applied (Poate and Daplyn 1993; Bernard 2002: 150). In the fisheries survey I divided the fishers' population into subpopulations based on gear differentiation, after which respondents were chosen randomly from each sub-population (Bernard 2002: 149). Then I made a gear classification of fishers using trammel net, mini-trawl, long line, gill net, and crab catchers. The number of fishers-respondents was determined proportionate to the population number of Kasai (Table 4).

\begin{tabular}{lll}
\hline Type of fisher & Total & $\%$ \\
\hline Trammel netter & 60 & 61.9 \\
Mini trawler & 17 & 17.5 \\
\hline Long liner & 4 & 4.1 \\
Gill netter & 9 & 9.3 \\
Crab catcher & 7 & 7.2 \\
\hline Total & 97 & 100.0 \\
\hline
\end{tabular}

Table 4. Number of fishers according to the gear used in Kasai ( $N=97)$.

\section{PATRONAGE NETWORKS}

Pelras (1996) pointed out that in the patron-client system leading individuals and their followers are linked to each other by a number of reciprocal duties and rights. In Makassar and Bugis hierarchical societies of pre-colonial times, every leading nobleman was at the centre of such a network or clientele. The relationship between patron and client is voluntary and based on a moral contract (Schrauwers 1999; Bourdieu 1990).

I define a patron-client relationship in Berau as an asymmetric but mutually dependent relationship between a patron and his clients or followers which is based on services exchanged in the economic and political realm in a historical inter-island network between Kalimantan, Malaysia, and Sulawesi. In Bugis communities, this network is called the punggawa-sawi relationship. The word punggawa originally comes from the Sanskrit word for a ship's captain, while the term originally sawi refers to a crewmember (Pelras 1996). In today's socialeconomic and political networks these terms have obtained wider meaning as boss or trader, and dependent of a punggawa respectively. These patronage 
networks apply both to aquaculture and to fishing (punggawa pa'kaja) activities (Pelras 2000) to the effect that one patron can have several dependent fishers and pond farmers at the same time who all deliver shrimps to him, but from different origins.

In Eastern Indonesia and in Kalimantan where Buginese are the dominant social class a patron-client relationship exists between fishers or pond farmers (followers) and the entrepreneurs (patrons or punggawa). The punggawa lends money, in terms of boat or gear or production costs to the fisher engaged in his network, and the debt is then repaid by the fishers in instalments by deduction from the sale of the fish. Levang (2002) clearly differentiates the punggawa from the moneylender; the patron providing a loan to fishers on rather different conditions. The loan can be used to buy a boat, engine, or fishing gear and can be paid back. It is different from the fisher's obligation to pay the debt to a money lender in a punggawa-sawi relation, as long as the debt is not repaid the client is obliged to sell his catch to the patron (Levang 2002: 8). It means that the fisher remains dependent on the punggawa. To secure repayments the patron and the client must remain involved in the same kind of business. Another condition, as Levang points out, is that confidence building is the key of the patron-client system. If the client is still young or a newcomer to the area then the patron will ask his relatives to be accountable for him. A patron then will give priority to his own relatives for reasons of trust (Levang 2002: 21). We can clearly observe these interactions in Kasai, as this article will show. It is interesting to know the life history of a major punggawa in Kasai in this context:

Abdurrasyid (AR) was born in Muara Pasir in 1949. He came to Kasai in 1994 and brought 11 fishers from Muara Pasir Tanah Grogot. When he was in Muara Pasir AR started as trammel net fisher. AR has got five children and married in 1967. He went to primary school until sixth grade in Muara Pasir. Formerly he bought fishes, wild shrimp and kembung fish and carried around two tons to Samarinda and Balikpapan. So when he had enough money he decided to buy shrimps directly, he asked for help from the Cendana Company. AR came to Kasai to follow his mother when she was following Haji Baco. AR's parents and his siblings are staying in Kasai as well. Currently AR has 24 fishers within his patronage network. All children except the oldest one are fishers. AR sees that the business is fine and he is satisfied as four of his children have been to Mecca. AR admitted that his wife's participation is needed to run the business (Interview with Abdurrasyid (69 years), Kasai, 29 February 2008.)

In fishing in Kasai village, it is common to see that fishers are engaged with one of the punggawa who collect and buy their shrimp or fish production. At the time of the field research in Kasai there were seven punggawa. The number of engaged fishers for each boss varied. Abdurrasyid for instance had 24 fishers and Rahmani had 60.

Trust is a main aspect in maintaining the relationship between patron and client. According to both bosses at least, their clients sometimes cheat 
them by selling shrimps or having their catch weighed to other patrons. Since this relationship is based on trust then the solution for the problem needs to be found persuasively. If there are fishers that do not concur to this kind of relationship then the consequence is that all the fishers' debts have to be paid before the relationship can be stopped.

Fishers have no opportunity to go for the best price on the market as they are a "price taker" that is, they are dependent on the boss. Shrimp prices are determined by each boss individually hence can differ from the one to the other punggawa. I will give an overview of shrimp prices in Kasai. There are two prices, namely the so-called direct price (harga langsung) and the commissioned price (harga komisi). Direct price means the price that is directly applied during transactions between the fisher and the trader, while the commissioned price is known as the selling price that is deducted to repay a debt instalment for an engine, fishing gear, or other debts for costs like fuel and ice. For example, a fisher in Kasai can bring home net cash of more than IDR 500,000 per trip after expenses are deducted and the instalment is paid (see Table 5). All records of both debts and instalments are documented in a book and each fisher has his own account book.

\begin{tabular}{llll}
\hline Shrimp Size & Punggawa's Price & Trader's Price & Price Difference \\
\hline 20 & 120,000 & - & - \\
25 & 95,000 & - & - \\
30 & 88,000 & 92,000 & 4,000 \\
35 & 77,000 & 80,000 & 3,000 \\
40 & 64,000 & 72,000 & 8,000 \\
45 & 54,000 & 62,000 & 8,000 \\
50 & 48,000 & 57,000 & 9,000 \\
55 & 41,000 & 48,000 & 7,000 \\
60 & 35,000 & 41,000 & 6,000 \\
65 & 30,000 & 37,000 & 7,000 \\
70 & 27,000 & 37,000 & 10,000 \\
75 & 22,000 & 37,000 & 15,000 \\
80 & 18,000 & 36,000 & 18,000 \\
85 & 17,000 & 35,000 & 18,000 \\
90 & 15,000 & 30,000 & 15,000 \\
95 & 13,000 & 29,000 & 16,000 \\
100 & 12,000 & 28,000 & 16,000 \\
\hline
\end{tabular}

Table 5. Different prices of shrimps with punggawa and traders (in IDR). (Source: Punggawa in Kasai 29/02/2008 and shrimp company CV Surya Indah Perkasa.)

Of the 97 fishers in Kasai 73 revealed to have an arrangement with a punggawa. It means that a more or less permanent loan from this patron is needed to 
maintain the fisher's livelihood. It is very common that fishers in Kasai have a loan from a punggawa. Survey data shows that the majority (75.3\%) of the respondents have a loan. In addition to that 47 out of 60 trammel net fishers $(78.3 \%)$ and 13 out of 17 mini trawl fishers (76.5\%) have a loan for their livelihoods. It means that financial access of fishers was strongly supported by the patrons.

Another fact is that most fishers have no savings for maintaining their livelihoods. Survey data shows that $82 \%$ of trammel net fishers and $94 \%$ of mini trawl fishers have no savings. It is relevant to know how these patronage networks develop, in other words, how fishers choose their boss and how a boss searches for clients. Fishers usually choose their patron or boss based on a stimulus of some kind. For example, the selling shrimp price was an important factor on how fishers choose his patron. The group of Haji Husin has another stimulus, namely that he gives an award per month to the fisher who has a good catch. If one of his fishers is very active, meaning he spends more time fishing, then the punggawa will give the fisher a television. This approach is used by the punggawa to achieve his set target catch per "one water" or fortnight.

Meanwhile the boss will choose certain fishers to be his clients under the condition that the fisher shows a good catch, proved by the receipt (nota) brought to the punggawa. If the fisher yields a low catch then the punggawa does not want to give him a loan. Another important condition for the patron to select a client is trust. If one fisher is already engaged with a punggawa then he has to sell the catch to that patron and not to other patrons, even if his patron gives him a lower price compared to others. Concerning the trust between patron and client and how a punggawa relates to his fishers, one punggawa in Kasai said:

If the engaged fisher continues to sell his catch to another punggawa and does not comply in giving his catch to his patron on three proven occasions, then the final decision is that the fisher has to pay off his debt to us, as we are his patron, and only after that he can go to other punggawa (interview with Abdurrasyid (69 years), Kasai, 29-2-2008).

In addition, the bosses in Kasai also cooperate among each other. A fact from the field shows that Haji AR has an economic collaboration with the patron Haji Husin in providing trammel nets. The first punggawa buys from the second one to fulfil the need of nets of the former's fishers. The way they agreed about the repayment is that the first punggawa will pay three instalments starting one month after the net is delivered to the fisher. ${ }^{4}$

Interviews make clear that when an engaged fisher does not feel satisfied with the political-economic support from his patron, then he can move to another boss. Yet, for the dependent fisher, maintaining his relationship with the punggawa, as informal leader in the village, is more important than his

4 During the interview, Haji AR showed me a paper stating that his fishers has borrowed for buying gondrong through punggawa Haji H which amounted to more than IDR 19 million. 
frustration about the patron. The situation was reversed with Amin who was originally the client of Haji Husin. During the village head election, Amin did not support punggawa Haji Aminuddin to become the village head. However, to still show his respect to him, Amin consciously exchanged his original patron, Haji Husin, for the new punggawa Haji Aminuddin.

Another case is Eswahyudi who is a follower of a patron in Teluk Semanting. He observed that in 1998 in this village, when fish selling prices were high, a new punggawa successfully attracted followers by giving them a free boat and engine, and lending them fishing gear. But nowadays, as the fishing income has generally decreased the dependent fishers have to pay for all those things themselves instead of being given to them by their boss.

Normally a punggawa will give the fisher a loan to get a boat, engine and fishing gear. For example, say his total loan is IDR 10 million. If the fisher is active, he can return his loan in less than one year, because in one trip during the good season a fisher can generate IDR 1 million. Some fishers can repay all their debts to the punggawa, but others do not manage, and remain fully dependent upon their boss. We have observed that some fishers have been to Mecca. To be able to conduct a pilgrimage to Mecca was the highest priority to them because not only was it very important in the view of religious achievement and the status, but also a fisher who has been on pilgrimage and become Haji indicates that he has already freed himself from being indebted to a punggawa.

\section{LIFE HISTORIES}

Trammel net fishing is the most popular in Kasai, not only as the main gear type, but also as a diversification strategy for fishers who mainly use other nets and have access to land. Below I present different livelihood histories to indicate the diversity.

\section{A trammel net fisher: Changing gears over time}

Abdul Samad (AS) was born in Semanting (Berau) in 1972. His first name was Syamsul Alam before his name changed. He lived with his parents and worked for an uncle named Lasse, who was a shrimp fisher for the production of shrimp paste (terasi) in 1980s. He is married to Rusnani, a daughter of Haji Singkong (the oldest tambak farmer who lived in Kasai), and had two children. The first child was born on 1 January 2002 and the second one was on 13 December 2003. AS first helped on trap fishery $(\operatorname{tog} o)$. Locations for trap fishing at that time were in Tanjung Buncit and then changed to Tanjung Budi. Trapping was daily work. After working for two years AS could buy a new togo himself, he bought this from his uncle. He worked on trapping until he graduated from elementary school in 1986. When he moved to Kasai he was a fishing crew for Johansyah, a trammel netter. The boat and gear owner got $80 \%$ of the harvest and the remainder went to the crew. The owner's parts consisted of boat, engine, fisher, and gear returns calculated as four parts or $80 \%$ of the total income. He worked for Johansyah for two years selling his shrimp to the boss. AS remembered the catch was valued as IDR 20,000 per fishing period of two weeks per month and he could cover 
the living costs of his parents of around IDR 18,000 while he used the remaining IDR 2,000 for himself. When he was not a crewmember anymore, his boss, Haji Adam, gave him a ketinting outboard engine boat 3.5 PK (brand Robin) to fish. The boss gave it for free but AS had to sell the shrimp harvest to him. The boat price and its outboard engine were IDR 18,000 at that time. It had an outboard engine that was commonly used before most fishers replaced it with a Dongfeng 5 engine. White shrimp was worth IDR 3,000 per $\mathrm{kg}$ and there was no sizing. AS had this boat for one year, then in 1990 he borrowed money from his boss Haji Adam to buy a second-hand fishing boat with Dongfeng 12 PK engine and he paid IDR 500 thousands as a down payment. The price of this engine was IDR 1.2 million and he continued to use a second hand trammel net. This was the situation for two years. AS still uses a trammel net until the present day. After he had worked for three years AS was able to repay his debt on the boat and engine to his boss. He said that he is now a free fisher, meaning one who owns their equipment including engine and boat, but fishing gear and production costs are paid by his boss. AS remains associated with this boss. He gave the following reasons for it: it is to remember the help that he received from his boss, and the location of the boss as shrimp collector was close to his place. Also the price margin between the market price and what he receives for his shrimps from his boss are small compared to other collectors. Later AS increased the engine capacity from the 18 PK motor he used for four years, to one of 23 PK for another three years. However, as he faced problems with the engine, he changed it again to $20 \mathrm{PK}$, the motor which he uses to date. Currently AS can save IDR 150,000 and he has been acting as head of the hamlet since 17 June 2003 for which he receives a salary of IDR 100,000 per month. Asked where he goes fishing, AS says that he says he knows that the good fishing grounds for trammel nets are Selalang, Badak-badak, Gedung, Tanda-tanda, Pegat, Daun Kuning, Buntungan, and Tengker which he can reach in about 30 minutes from the village. AS prefers to go to Selalang and Gedung. However, he would change to other fishing grounds if the usual places were less productive (Samad (36 years), Kasai, 4-2-2008.)

From the above life trajectory, it is understood that a fisher's experience involves using different gear to search for a better livelihood. Diversified gear is part of a livelihood strategy developed by fishers in Kasai as they know the seasons well and apply appropriate fishing gear in their coastal fishing grounds. In addition, fishers are involved in the patronage networks with their bosses to reduce the risks of the fishing operation, maintain access to the shrimp market, and to keep up a social and economic safety net.

Compared to trammel net fishing, those owning mini-trawls are the second most numerous in Kasai $(\mathrm{N}=17)$, but they diversify much less and their risks are also less than for the trammel netters.

\section{A mini trawler: Limited opportunity to change the gear}

Rupi (R) was born in Ulingan nearby Teluk Semanting village. In the 1980s he went to Kasai after moving from Pegat and then to Mangkajang. He married in Kasai and has stayed there up to now. When he was 12 he followed his parents

5 A famous Chinese motor industry. 
to Pegat to operate fish trap (kelong). In Kasai he first caught fish using a trammel net for three years. He used an outboard engine boat (ketinting) of 3 PK and had five sets of trammel nets.

He said that he is less satisfied about the catch so he has tried to use a mini-trawler until present. Trammel nets produce a good catch but the cost is high. R perceived that a trammel net (gondrong) can be used longer than one month, because it often tears. It is not the shrimp that causes this but the fish. Whereas with a mini- trawl net, although one gets less fish compared to trammel net, it can be used years longer than of trammel net, except of course when the net becomes entangled (tersangkut) then it will be torn. When it is torn one just buys a new one, otherwise it lasts 4-5 years. Maybe a trawl is a bit expensive but I have no other job. So due to less catch $R$ has moved to trawling since 1995. At that time almost all Kasai fishers changed to mini-trawl from gondrong. R moved to trawl since he felt that the production cost of trammel net had increased and the gear was broken quickly therefore it had to be replaced, while a trawl can be used longer than a trammel net. R keeps using mini-trawl until now as he has a skill for this fishery. When the interview took place $\mathrm{R}$ said that he actually would prefer to have to a fish trap (kelong) but he couldn't afford it as there was no loan available. He believed that could give him more income. Currently, he has got five children in which four out the five children attend school outside Kasai. The mini trawl is not used at konda time or air mati (see section 3.2.2). R uses an outboard motor $20 \mathrm{PK}$ and the length of trawl is 5 depa long. The catch is about $10 \mathrm{~kg}$ bintik shrimps sizing 150,200 , or 250 per trip. The price of these shrimp is IDR 11,000. The production cost consists of 10 litres fuel, ice for IDR 5,000, cigarettes for IDR 10,000. The net income is around IDR 30,000. The shrimps are sold to punggawa Haji Bidin or Daeng Kulle and they take them to the market at Tanjung Redeb. Within a one day fishing trip $\mathrm{R}$ has 4 haulings and between two haulings the gear is left for two hours. The fishing ground for trawlers is in Selalang, formerly in Pegat, about a half hour from Kasai by boat 20 PK. Since he is not sure about finding more shrimp in other places $R$ does not move from there. He is aware that movement means higher cost of production. He sets himself the target of catching 6-7 kg a day; if he manages, he can continue fishing. But if he catches only $5 \mathrm{~kg}$ or less he prefers to stay at home instead (Rupi (55 years), Kasai, 9-2-2008.)

Shrimp and fish caught by fishers in Kasai were varied. They strategically attempted to capture more fish in the good fishing grounds, mainly during the good season which is the north season.

\section{A gill net fisher: making strategic choices}

Eswahyudi (E) is a gill net fisher in Teluk Semanting village. He was born on 8 August 1974. As a fisher, he usually goes fishing at 7 a.m. and returns at 2 p.m. But sometimes it varies, he goes at mid-day and returns at night. Gill net fishers in Semanting normally start fishing at guris 3 or 4 until guris 6 and continued with undur 1-3. ${ }^{6}$ Some others do not go at that time. After this time they stop fishing, as there is no fish in the sea, E believes that there

6 Fishers in Teluk Semanting recognize nyorong as guris (see Table 3.16). Guris starts from guris 1 up to guris 6 . After high tide, fishing day starts again with undur which begins with undur 1 up to undur 3 . 
is no fish as the water is clear. But E said usually fishers in Teluk Semanting start fishing at guris 4 . E said that gill net fishers in the village have 9-10 metres boats that are $130 \mathrm{~cm}$ wide with inboard engines known as Dongfeng of $24 \mathrm{HP}$. They use local gill net gear called pukattasi, the mesh size of the gill net is 4 or 5 inches depending upon the fish target. If the mesh size of the net is only 2 inches then it is for the smallest fish they catch named selangan. There is also a net with mesh size $3 / 4$ inch for catching small species up to 6 inches to catch bawal (pomfret or pampus argenteus) If using a gill net with mesh size 4 or 5 inches we can catch all sorts of fishes but 6 inches is only for valuable fish species. According to $E$ the value of highest catch is around IDR 2 million per trip. It means that the catch is $50 \mathrm{~kg}$ both fish and other fish. Fishers catch throughout the year even from January to March, which is an uncertain period when winds cannot be predicted, and the catch is small. It is in contrast to the period from August to November when fish is abundant. Gill net fishers need 5 litres of fuel per trip. They go fishing for 5 hours so they do not need ice. Fishing grounds for trammel net and minitrawl are in the same places without any restrictions. Fishers are moving around within these areas following the fish. Near fixed objects, like bagan and the sunken tanker, where gill nets cannot be used long lines are used. While crab fishers operate along the riverside and estuary of the Berau Delta (interview with Eswahyudi (24 years), Teluk Semanting, 22-5-2008).

\section{PLACE MAKING AND CONTINUOUS SOCIAL SPACE}

Migration is an issue that is important to raise here as it is part of the fishers' strategy to find a better livelihood. Migration is a response from rural communities to deal with negative factors such as environmental degradation, population growth or economic pressures (Haan et al. 2002). Most of the migration literature deals with land-based rural communities, and hardly any study deals with migration by fishers. Interestingly, migration for fishers is a normal part of their life experience. Since fishers do not cultivate the resource, they depend on the fishes' movements at sea. Over time, as marine resources are dwindling in the Indonesian coastal waters, Bugis fishers have moved from one island to another and from one place to another. In the Berau Delta, migrants came from other coastal places in Kalimantan, like Pasir, or across the sea, from Sulawesi. Villagers therefore have a seaward orientation (Pauwelussen 2010) in keeping up social networks.

Most of the people living in the coast of East Kalimantan are from South Sulawesi, ${ }^{7}$ mainly Bugis. Pelras (1996: 320) stated that in Kalimantan (Borneo), Bugis settlements in areas around Pontianak and Mampawa on the west coast and in Pulau Laut, Pegatan, Pasir, Kutai (especially in Samarinda), Bulungan, and Gunung Tabur (Berau), controlled the upriver trade. He further argues that Bugis migration is an economic strategy which is often connected with the resolution of a personal conflict, an affront received, political insecurity

7 Pelras (1996: 12) notes that the four main ethnic groups in South Sulawesi are Bugis, Mandar, Toraja, and Makassar. He adds that Bugis people distinguish themselves according to their former major states (Bone, Wajo, Soppeng, Sidenreng) or groups of petty states (those around Pare-pare and Suppa on the west coast; those around Sinjai in the south). 
or the desire to escape either unsatisfactory social conditions or undesirable repercussions from an act of violence perpetrated at home. It is known that Bugis have migrated and developed settlements throughout the Indonesian archipelago since the end of the seventeenth century.

[I]n east Borneo, La Ma'dukelleng concluded political matrimonial alliances with local rulers just as he would have done in his home country; thus he married one of his sons to one of the Sultan of Pasir's daughters and, later, their daughter to Sultan Idris of Kutei, while he himself became Sultan of Pasir. He was also active in organizing other Wajo communities all down the east coast of Borneo, each under its elected chiefs. Having obtained from the previous Sultan of Kutei the right of settlement for Bugis in Samarinda, a strategic settlement near the mouth of the Mahakam River, somewhat downriver from the Kutei capital, he later also obtained from Sultan Idris monopoly rights over the export of products from the hinterland, including gold-dust, benzoin, camphor, dammar, gaharu wood, rattan, birds' nests, beeswax, bezoar stones, and rhinoceros horn (for which, however, only Kutei Malay were permitted to trade upriver), and of sea products such as tortoise shell, turtle eggs, agar-agar, and trepang. Some Bugis leaders were granted titles by the Sultan which put them on a par with the Malay nobility and qualified them for intermarriage with the ruling dynasty (Pelras 1996: 321-322).

\section{Case of Amin: From Tinobu to Kasai, and becoming head of Pokmaswas ${ }^{8}$}

Amin (A) was born in Southeast Sulawesi in 1969. He grew up there until he was 6 years old. Then he moved with his parents to the Bone district, South Sulawesi where he lived until he was 12 years old. He went to the SD [primary school] at grade 6 and before he passed SD he moved with his family to Simpang Empat village in Batulicin South Kalimantan. This move was due to the fact he had family there and some economic opportunities, and the availability of land for agricultural activities. He then finished primary school in 1982 and lower secondary school (SMP) in 1985 in Batulicin. Salman (field officer) was in the same school. A continued to study at the higher secondary school (SMA) "Garuda" in Kotabaru and graduated in 1988. While he was in the SMA he worked as labourer in a housing construction project where his wages was IDR 5,000 per day. Every week he went down to parents' house and he continued to get money from them. Furthermore, he followed religious meetings every night for five months and became the Moslem teacher's assistant until 1988. Later he followed his parents to work in gold panning in Mangayapa. The gold price was IDR 18,000 per gram and he could earn IDR 30,000-50,000 per day. A sent money to his parents for two years. As the gold location was not good A moved to Batubalik to do the same. The economy was getting better as he earned IDR 50,000-100,000 [per day] for 1.5 years. A married his first wife, Fauziah from Martapura, in Telawi in 1992 and divorced her one year later. In January 1993, he moved to Kasai to follow his parents who had gone there already in 1991. When A travelled to Berau he stopped in Merancang for two days and people there asked him to go with them to Kasai. In Kasai he first worked as daily labourer for four months with a wage of IDR 7,000 per day. After that, for five months A became a fisher in a crew with

8 Kelompok Masyarakat Pengawas "the surveillance organization". 
the assistance of his cousin. The income of the fisher crew was IDR 50,000 per month net; the total income was divided into three parts, one for the boat, and one for the owner and the rest for the crew. A used his initial loan to buy a boat priced IDR 300,000. The fishing engine was provided on credit by his boss Haji Adam. At that time white shrimp sized 60 was IDR 15,000 per kg. He bought a net (brand "Arida") for IDR 12,000 per piece which had to be replaced every 15 days. A was appointed as general staff of the village in 2002-2004. At that time Kasai was not a formal village yet and the head of the village-to-be Kasai was Haji Jebar. The main task of $\mathrm{H}$ was to make ID cards for people there. As village staff A was paid a salary of IDR 300,000 per month. A sold fuel (solar) in the village that he bought from Tanjung Redeb or Merancang. His second wife also helped the family income by opening a small kiosk. A became head of Pokmaswas in Kasai. The establishment of this surveillance organization was initiated in a meeting on the 23 May 2006 which was attended by ten people, with village representatives coming from different hamlets. Officers from Dinas and police were present. A, as the representative of hamlet 3 (RT 3), was voted to become the head. During his time in Kasai A has had different bosses starting from Haji Adam, then Haji Baco, Haji Aspan, Haji Abdusrrasyid, Haji Husin and lastly Haji Aminudin. (Interview with Amin (39 years), Kasai, 25-1-2008.)

In the Kasai case, the population is mostly immigrant and is dominated by people who have migrated since the 1990s from the Pasir district in East Kalimantan, mostly from the villages of Pasir Mayang, Pondong, and Air Mati. These immigrants live in the upstream part (hulu) of the village which is sometimes called Kasai Baru (new Kasai) while local people live in the downstream part (hilir). The immigrants stay in the vicinity of their patron. One of the immigrants from Pasir is the village head named Rahmani. Below I share part of his life history:

\section{From fisher to boss and village head}

Rahmani (R) is the village head of Kasai and is known as the youngest punggawa and collector of shrimps. He was born in Banjarmasin, South Kalimantan, on 10 June 1968 and grew up there for 21 years. He has had a few jobs ranging from opening a food stall, becoming a taxi driver's assistant and a motorcycle driver (ojek). In 1990 he started to live in Pasir Mayang village (Pasir district) with his mother and he got married there. During his life in Pasir, he worked on a dredging activity of Kapal Musi 22 and as a salt finder and diver in the mining industry. After that, he became a gill net fisher and got a loan from a boss in Pasir Mayang. $\mathrm{R}$ decided to move to Kasai to follow relatives who were there already. When he first came to Kasai R started as a gondrong fisher and learned how to handle the sea with his brother-in-law for several months. The fishing economy went up and down but it improved since he became a boss with his owns boats and clients. In 1998 when the economic crisis hit Indonesia, until 2003 R was successful having 14 boats and 60 fishers. His assets also included six iceboxes and five generators. He could produce at least $150 \mathrm{~kg}$ of shrimps per day and reached a profit of IDR 1 million per day. He then was appointed as village head by the district head for his first term in 2004. $\mathrm{R}$ is connected to CV Novianti, a shrimp buying company who works both in Anggana, the Mahakam delta and in Banjarmasin. Shrimp 
production consists of $90 \%$ white shrimps and 10\% tiger shrimps. He feels that the production has decreased in the last three years and he is thinking about expanding his business outside Kasai. $\mathrm{R}$ believes that his initial business has never stopped even though it is deficit, but it has to be operated even if slowly. If his followers are not satisfied and go to another boss to sell shrimps he says that he will solve the problem by approaching his fishers and restore their trust as he sees this is the fundamental aspect in their cooperation. (Interview with Rahmani (40 years), Kasai, 22-1-2008.)

I wanted to know why people had chosen Kasai for their settlement. I asked Johansyah, a senior village member about it. He contended that he had chosen Kasai as people there could easily get clean water compared to the Pegat area. In Pegat one needs to get clean water from other areas or rely on rain water. According to our survey data, most of fishers (66\%) moved to Kasai after 1995. Only six fishers were there before 1980, leaving 28 fishers still there from their arrival in the period 1980-1995.

Based on the life histories of different fishers above I conclude that a fishing based livelihood is not only a means to make a living. Fishing as a livelihood also includes knowledge and values (Long 2001), and it has a long history, often including a trajectory of migration and strategies of place making that they have practiced over time during their life history.

\section{FISHING PRACTICES, LOCAL KNOWLEDGE, AND SEASONALITY}

Trammel netters generally start fishing around 06.00-07.00 a.m. until midday during fishing days. Some fishers will come back around 6 p.m. and do not go fishing after that. Fishing activities depend upon the season and the catch they have but they do not have a target. They go out fishing for a continuous period of two weeks following the moon cycle, which is known as "one water" (satu air). At full moon when the tide is highest or the so-called high tide (air besar), and at low tide (air surut), also called konda, the trammel net fishers do not fish. Within one month they effectively fish for 20 days.

Fishers in Kasai are very knowledgeable of seasonality. They distinguish three fishing seasons; namely the north season (musim utara) from October to March, the south season (musim selatan) from June to October, and transition season (musim pancaroba) in between. According to them the north season is known to be the best for fishing. The south season is known as the time of lesser catches, while the hardest times to fish is the transition season running from April to June every year. These fishing seasons apply mainly for trammel net and mini-trawl fisheries. The other types of fishers also recognize the seasons with little variations. Trammel net and mini-trawl fishers fish in the same fishing grounds in the more shallow waters, while gill netters and long line fishers go further toward the deep sea. Gunawan and Visser (2012) presents a map of fishing grounds for different gear types in the Berau Delta.

Since fishing depends upon seasonality, I asked a shrimp buyer in Tanjung Redeb about the variation of shrimp production in Kasai during a year. I am sure that data provided by the shrimp trader here is not recorded by local 
government and I know that most of the white shrimps in Kasai collected by punggawa were bought to Suryadi, ${ }^{9}$ the representative of SIP Company in Berau. It means that the data is not transparent and the company does not provide information to Dinas. According to data from 2008, the highest production of shrimp fishery was reached in November, calculated at 10 tons, and the lowest one was in July calculated at 4.4 tons.

In addition to the survey data above, I arranged a FGD in Kasai (13 February 2009) to which I invited fishers using different gear. During discussion I was told that the type of livelihoods which were important for their households, the local mapping of fishing grounds for different fishing gear used by villagers and outsiders (andon), and conflicts about fishing grounds between locals and andon fishers (Gunawan and Visser 2012). Livelihoods in Kasai are diverse. People can earn money not only from fisheries such as trammel net, logline, mini-trawl, gill net, shrimp trap net, crab trap (rakkang), and scoop net but also from fish drying, jellyfish catching, shrimp-and-crab pond aquaculture (tambak), upland paddy, gardening, and opening a small village store (kiosk). Since we are speaking here of households, these activities clearly include the women as well. Women in Kasai help their husband in processing shrimp or fish to be dried. Meanwhile, in Teluk Semanting women process fish into fish snacks (kerupuk).

Practical knowledge based on long-time experience regulates their fishing operations. Fishers in the delta have found the good fishing grounds by experience and they know when is the best time and season to fish where. A gill net fisher explained his strategy for identifying fishing ground as follows:

To decide where to go to fish on certain days, sometimes we spread the locations. For example, today I am in Selalang and my friend is in Tiang, but we keep coordinating by meeting each other or by using mobile phones. After three days, the numbers of fish will be getting fewer, so if the fishes are not there anymore, we stop. I go fishing alone, but we know where we meet. We plan ahead where to go to find fish, we use our feeling based on our experience from the last year. In the south season, we go to Tiang and Buntungan. In the north season we go to Buntungan, Gedong, Sindring, and Bingkar. During the transition period we can go to anywhere. (Interview with Eswahyudi (24 years), Teluk Semanting, 22-5-2008.)

Coastal fisheries highly relate to the tidal system. Hutabarat and Evans (1985: 99) define the maximum tide as spring tide while the minimum tide is recognized as neap tide (see Figure 3). Spring tide happens on new moon and full moon times, while neap tide occurs during the first and the third quarter of the moon (Hutabarat and Evans 1985). In addition to that, Dahuri et al. (2000) point out that the tidal system in Indonesia can be divided into four types, namely diurnal tide, semidiurnal tide, mixed diurnal, and mixed semidiurnal. In the study area, the tidal system of the Berau Delta is regarded

$9 \quad$ Suryadi is representative of shrimp buying company named CV Surya Indah Perkasa (SIP) Berau branch. The head office of this company is in Balikpapan. 
as mixed semidiurnal tide, including the Berau River.

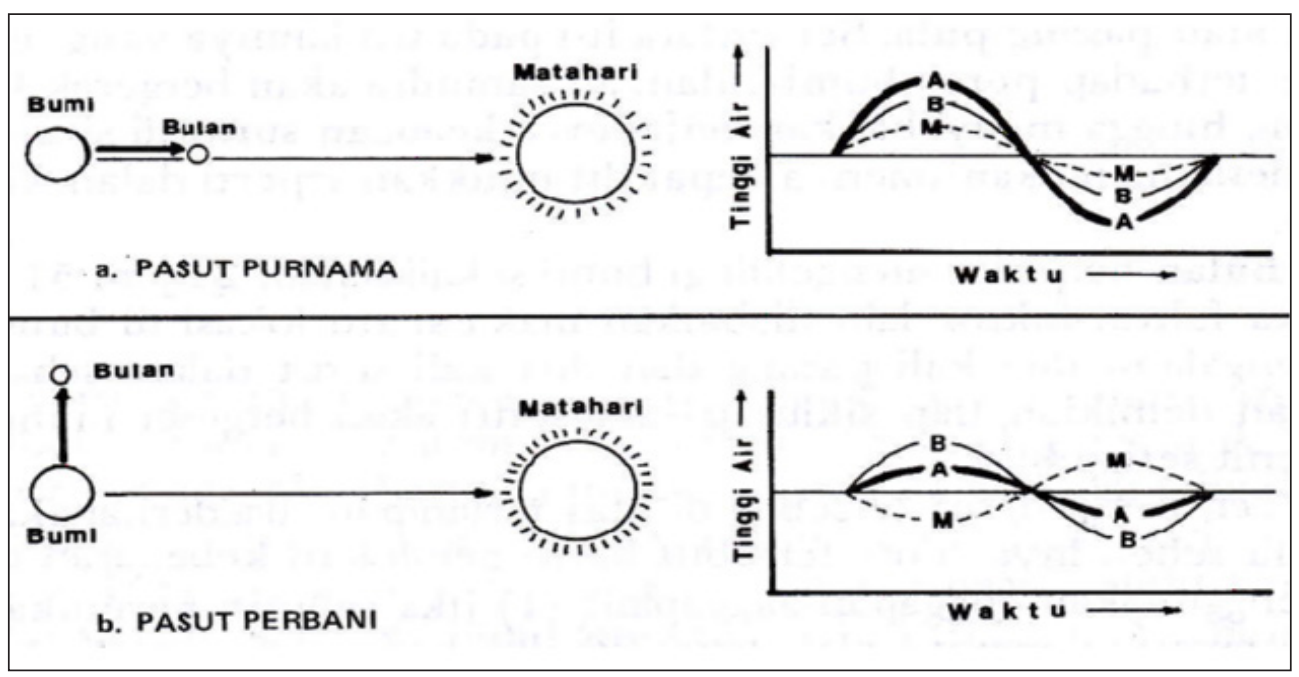

Figure 3. Position of the earth (bumi), moon (bulan), and sun (matahari) at spring (a) and neap (b) tides; $\mathrm{B}=$ moon's effect, $\mathrm{M}$ = sun's effect, and $\mathrm{A}=$ sea mean level (after Nontji 2005).

Fishers in the Berau Delta use their local knowledge in the fishing operation. They know the fishing calendar which is based upon the lunar calendar. For example they distinguish between low tide (air mati), when there is no current at low tide (gila-gila), ${ }^{10}$ incoming water (nyorong or guris), outgoing water (konda), and high tide (air besar). Fishers recognize several good fishing grounds according to seasons and gear usages. In addition, fishers have a local fishing arrangement of satu air (one water) which means that they go fishing every day during two weeks, so there are two periods of "one water" per month. Of the two weeks' time of "one water" they effectively fish for about 10 days (Table 6).

\begin{tabular}{lll}
\hline Days of month & Local name & Fishing day (Yes/No) \\
\hline 1 and 16 & - & Yes \\
2 and 17 & - & Yes \\
3 and 18 & - & Yes \\
4 and 19 & - & Yes \\
5 and 20 & - & Yes \\
6 and 21 & - & Yes \\
7 and 22 & - & Yes \\
\hline
\end{tabular}

10 I translated myself the concept of gila-gila and nyorong or guris. Gila-gila is local knowledge which refers to the fishing-off day as there is no current in the coastal waters so the drift trammel net gear cannot move to attract fish. 


\begin{tabular}{lll}
\hline Days of month & Local name & Fishing day (Yes/No) \\
\hline 8 and 23 & Konda or air mati & No \\
9 and 24 & Gila-gila & No \\
10 and 25 & Nyorong 1 or Guris 1 & Yes \\
11 and 26 & Nyorong 2 or Guris 2 & Yes \\
12 and 27 & Nyorong 3 or Guris 3 & Yes \\
13 and 28 & Nyorong 4 or Guris 4 & Yes \\
14 and 29 & Nyorong 5 or Guris 5 & Yes \\
15 and 30 & Air besar & No \\
\hline
\end{tabular}

Table 6. Monthly arrangements for trammel net fishing based on lunar calendar. (Interview with Amin (39 years), trammel net fisher, Kasai, 21-1-2008.)

The strategy developed by fishers is not public knowledge but individual or family knowledge. It may be kept within the family or shared with friends. Trust between different fishers using similar gear within the coastal fishing community is as important as normative rules, for example the prohibition of the use of mini-trawls in the rivers of Kasai and Pegat Batumbuk following the Presidential Decree 39/1980 on the trawler ban. It means social and symbolic capital constructed by the local fishers shapes the fisheries-based livelihoods in the coastal area.

The decision to go out at sea is based on information provided over time by fishers' friends, whether they have got shrimps or not, and on which fishing grounds. Generally, this information is correct but the catch has decreased. It is probably caused by other fishers as they come to fish in those areas. (Interview with Johansyah (58 years), Kasai, 21-1-2008.)

\section{LIVELIHOOD DIVERSIFICATION}

Fishers choose different kinds of gear such as trammel net, gill net, mini-trawl, and long line during different seasons and in different places depending on the presence of shrimp and fish resources. Some fishers strategically use more than one type of fishing gear. They may have a trammel net and a gill net or a trammel net and a long line in one boat depending on the fisher's calculation of the spatial and seasonal distribution of the catch, or they change their fishing techniques during their life time (for instance, from mini-trawl to trammel net). In addition to the usage of different types of gear to cope with daily or seasonal changes of catch, they extend into non-fisheries activities: agriculture, opening a small store (Ontita 2007). Also, the fishers build and maintain a trade network with other actors, like shrimp farmers and patrons.

Our survey data clearly show that fishers in Kasai have gear diversification as livelihood strategy. For example, trammel net fishers $(\mathrm{N}=60)$ also use other gears including mini trawl $(\mathrm{N}=3)$, long line $(\mathrm{N}=11)$, gill net $(\mathrm{N}=6)$ and they alternate with crab catching $(\mathrm{N}=2)$ during their fishing operations.

My key informant, Amin, told me that his wife sells from a small kiosk 
mainly to fulfil the needs of primary school pupils and village children. In addition, Amin sometimes engages in upland rice cultivation. Another case is Rupi, a mini trawler, who has upland rice cultivation as his most important additional livelihood. He can harvest two bins which is about $20 \mathrm{~kg}$ of hulled rice per bin, once a year.

Another example was given by Johansyah, a trammel net fisher and former village administration staff who tried to farm five years ago. Johansyah planted cassava but the roots were too attractive to wild pigs and the harvest failed. Now he plants jackfruit and orange mainly for home consumption. He says that it is important for the future to have this land rather than buying fruits and thus provide security of land that can be inherited by his children.

The survey results regarding livelihood diversification show that $63 \%$ of the total number of fishers in the survey in Kasai has diversified their livelihoods as presented in Table 7. Some fishers have access to land. Kasai is one of the few villages in the Berau Delta where a hilly hinterland allows the inhabitants to use gardening as an additional means of livelihood to fishing. Fishers are cultivating land ranging from 0.5 ha to 21.5 ha. I found that they generally do not have a letter of ownership through a formal cadastral registration. But locally, access and rights to land are well known and recognized.

\begin{tabular}{lllllll}
\hline \multirow{2}{*}{ Type of fisher } & \multicolumn{9}{c}{ Complementary livelihood means* } & \multirow{2}{*}{ Total } & \multirow{2}{*}{$\%$} \\
\cline { 2 - 5 } & Yes & $\%$ & No & $\%$ & & \\
\hline Trammel netter & 34 & 35.1 & 26 & 26.8 & 60 & 61.9 \\
Mini trawler & 15 & 15.5 & 2 & 2.1 & 17 & 17.5 \\
Long liner & 2 & 2.1 & 2 & 2.1 & 4 & 4.1 \\
Gill netter & 6 & 6.2 & 3 & 3.1 & 9 & 9.3 \\
Crab catcher & 4 & 4.1 & 3 & 3.1 & 7 & 7.2 \\
\hline Total & 61 & 62.9 & 36 & 37.1 & 97 & 100.0 \\
\hline
\end{tabular}

*Pearson Chi-square $=6.11$ (not significant)

Table 7. Livelihood diversification ( $\mathrm{N}=97)$.

Trammel net is the main class of fishing gear in Kasai. Some of the fishers have alternative livelihood on land like gardening and upland rice cultivation. Some others cannot afford to buy land as it is expensive. Most of trammel net fishers have no savings and they spend most on buying new gear and fishing goods.

As I mentioned earlier Kasai is known best for white shrimp fishery. Shrimp buyer Suryadi from CV SIP told us that between 2002 and 2005 the shrimp production in Berau went down as a consequence of the presence of trawlers from Malaysia - while these bigger trawlers have been banned in Indonesia since 1980. This illegal trawl fishing has very much contributed to the decreased production of shrimps in Berau, including Kasai. However, at the time of research, his company could get shrimps all right. 
Certainly the highest tiger and white shrimp production is there (in Kasai). I see every delivery time the highest amount is white shrimp. In terms of production Kasai is the best. We started to do business here in Berau because of Kasai. I started here in 1998 but Kasai was good for a long time before that. We were there in 1991 and heard that production in Kasai is good. In Kasai the shrimps are rich even in the very shallow water. (Interview with Suryadi (36 years), Tanjung Redeb, 12-2-2008.)

The economic crisis of 1998 has positively affected the shrimp production in Berau, because it is an export commodity that benefited from the lower value of the Indonesian Rupiah against USD which resulted in a higher price on the global market for exported shrimps. This of course was most profitable for shrimp buyers, traders or punggawa, but also for the fishers. In 2009 production costs were higher and particularly the limited availability of fuel for fishing operations meant that the income from fishing was a lot less when compared to 1998.

Johansyah mentioned that at the time of the crisis in 1998 within two weeks he could earn IDR 1 million per day. Ten years later, when the fuel price was high, catching shrimp became also hard because he did not want to move far away. In 1998 the fuel price was IDR 2,500 per litre and kerosene was IDR 2,000 per litre. In 2009 these prices had increased to IDR 6,000 and IDR 4,000 per litre, respectively. A gill netter in Teluk Semanting said:

Fuel is rare even in the Berau stations where fishers cannot buy it. Sometimes we search for illegal places to find it. There is someone who sells 20 litres but we have to pay around IDR 150,000 instead of the normal price IDR 105,000. But fuel scarcity is even harder. Now we do not care about the high price of fuel as long as it is available. (Interview with Eswahyudi (24 years), Teluk Semanting, 22-5-2008.)

Fishers in Kasai face problems with prices of both shrimp and fuel. They are dependent on the fuel price provided and controlled by their patron. This certainly affects the fishers' livelihood, especially since are not free to sell shrimps directly to the company for a better price, as they depend on their patron's trade network.

The price of shrimps set by the punggawa is lower as compared to the price we would get if we directly sold to the company. For example, the price of tiger shrimp sized 20 in CV SIP was IDR 160,000 per kg while with the punggawa it was only IDR 125,000 per kg. In addition to his profit margin, the punggawa also benefits from bonuses from the company. There are two marketing channels of captured shrimp in Kasai, one is from fishers to the punggawa and then delivered to CV SIP; the other is from fishers to the boss and subsequently to Pisangpisangan (by CV Apollo) and then delivered to Tarakan. From 1980-2002 CV Apollo through its cold storage exported shrimps to Taiwan and China. We (the fishers) felt the price of diesel fuel (solar) was very high. In order to tackle this problem, fishers mix solar with kerosene as we cannot afford to buy pure solar. By mixing these two the fuel cost is lower. Another thing is ice. I pay IDR 5,000 per trip for ice, and I pay a lower price through him. He also provides me with 
trammel net gear (brand "Udang") which he gets from Malaysia. (Interview with Samad (36 years), Kasai, 4-2-2008.)

From this interview we see that the punggawa benefit from the shrimp marketing process in Berau as they are the middlemen (Table 5). In Kasai, fishers mostly have a loan from the punggawa. We also learned that the fishers in Kasai in 2009 had to cope with higher prices for fuel and fishing gear which caused the fishing income to go down. They are indebted to their boss. Thus, macro-economic conditions affect fishers' livelihoods and forces fishers to invent strategies to deal with this situation. Fishers from the five different classes distinguished in our survey have different strategies to maintain and search for a better livelihood. In the next section I show examples of life trajectories of actors who carry out shrimp and fish marketing in the coastal frontier of Berau.

\section{SEARCHING FOR BETTER LIVELIHOODS: EXAMPLES FROM DIFFERENT CLASSES}

In this section, I show how some fishers manage to improve their lives by moving out of fisheries into related livelihood opportunities, using personal, family, and patronage networks, and knowledge from previous life experiences.

\section{Andi: From gill-netter to fish collector}

Andi Erson (Andi) was born in Pegat in 1967. He grew up and went to SD until the fifth grade. He followed his uncle and started to work as a gill net fisher in 1982 to catch ikan bawal. After ten years he became a fisher, he then changed to trade fishes and shrimps to Tawau and created a joint business with a Chinese businessman (toke) there. Andi did this job for three years. This patron in Tawau lent him, a gill net and he expected that the catch would be sold to him. The process is like this: the fishers catch fish and shrimps during one week and then we collect the produce and take it to Tawau. When the fishers' catch went down, this negatively influenced Andi's income to the extent that he could not cover the production costs. Andi decided to change to selling fish and shrimps to $\mathrm{CV}$ Tunas Mandiri in Tarakan for five years as he had a family relationship with the company owner. The process was like that in Tawau: during low tide, he delivered the products to Tarakan. From Pegat to Tarakan was a one-day trip. But the catch decreased and it was hard to maintain the business. Later, he changed to selling fish in Tanjung Redeb to Pak Sukirman as Andi believed him that there was a good market in Samarinda. Andi met a buyer in Berau when he looked for bawal and tenggiri fish through Haji Maman, the boss of the fish traders in the market. Later, Andi cooperated with Sukirman to supply fish for restaurants in Samarinda. Currently Andi is the head of the hamlet in Pegat and he trades fish, shrimps and shrimp paste (terasi). Andi has a clientele of 22-gill net fishers, seven togo fishers and ten terasi fishers. The latter fishers catch the raw fish to make shrimp paste of small shrimps called hambaring. Usually women make the shrimp paste in this village. (Interview with Andi (41 years), Pegat, 28 -2-2008.) 
It is important to know how Andi, who now is a boss in Pegat Batumbuk in the Berau Delta, sees the sea as the basis for a livelihood:

I wanted to be a collector because then I do not need to push myself to go to the sea. I really want to operate a shrimp pond (tambak). But it needs much money, I think, since I have been to Jepara with Pak Amin where there is a professor who developed a shrimp pond system which cannot fail. Here in Pegat the ponds cannot be reached by road, so even if the tambak is successful, we still remain waiting for good market access. Many examples have shown, such as in Tarakan, that there are often robberies or even murders in pond areas. I am really scared that when we want to harvest from the pond then the robber might come. (Interview with Andi (41 years), Pegat, 28-2-2008.)

I had an opportunity to talk with Haji Nassir, a local entrepreneur who owns the CV Piposs company based in Tanjung Redeb. This fish buyer company is the main fish producer playing a very important role in supplying fish and other marine products in Berau. When I asked him how much fish he produces for the local market in Berau, he told me:

Basically, my calculation is that $80 \%$ here is produced by myself and $20 \%$ is from outside Berau. It is clear that if my vessels do not enter landing site of Tanjung Redeb market (to supply) then there will be no fish at the market. (Interview with Haji Nassir (36 years), Sambaliung, 24-12-2009.)

I met Haji Nassir at his office in Sambaliung on 24 December 2009 with an introduction by Salman, the Fisheries field officer. Meanwhile an officer of the Dinas had just informed me that Haji Nassir was nominated to go for the national competition for the best performing marine fisher, called Adibakti Mina Bahari , after he had obtained the best position for this award for the province of East Kalimantan in 2009 he was now eligible to compete at the top level. I tried to capture the life history of this important actor:

Haji Nassir (HN) was born in Barru, South Sulawesi in 1972. His complete name is Haji Muhammad Nasir Juneid. He followed primary school in Takalasi, secondary school (SMP) in Madello, and he completed secondary technical development school (STM Pembangunan) in Ujung Pandang in 1992. He bought 13 trawlers with the support of someone in Malaysia. He recognized himself as a pioneer of trawl fishing five years ago. $\mathrm{HN}$ is the owner of CV Pippos. This company has three lengkong or purse seine vessels, five courier vessels in Berau and two in Tarakan. The courier vessels collect the catch from other boats at the fishing grounds and bring them back to the fish base. When the vessels go to the fishing grounds, they bring fuel, food and water. CV Pippos can produce five tons of fish per day. It has an icemaker and a 80-ton-storage. The fishing operation is only when the moon wanes or waxes (bulan gelap) around 20 days per month. He mentioned that the vessel could only store 30 tons since the fish has to be taken out when there is a clear moon (waktu terang bulan) to sell it on the Berau market during 3-4 days. During these days there is no fishing activity for purse seiners. The fishing grounds are four miles seawards, but they usually fish at ten miles since the height and width of fishing gear are $100 \mathrm{~m}$ respectively. They do not 
want to fish at a $40 \mathrm{~m}$ depth since the nets will easily be caught behind stones on the sea bottom. The location of fishing grounds in Talisayan waters is around six miles from the coastline. They have a fishing permit from KKP (from the Ministry of Marine Affairs and Fisheries) in Jakarta. Some local people in Talisayan have complained to purse seiners as they affect the local catch. (Interview with Haji Nassir (36 years), Sambaliung, 24-12-2009.)

It appears that Haji Nassir was the first person who used trawls in Berau, but because of the Trawler Ban from 1980, he was forced to cooperate transnationally with an entrepreneur from Malaysia to fish in Berau waters (see below). He exchanged his trawlers for purse seiners in 2007. He now operates in the fields of fresh fish trading, frozen fish and ice factories.

At that time the price for a trawler was IDR 238 million, and in Malaysia it was permitted to use trawlers. I took the initiative to use this gear and coincidently there was a Malaysian person who wanted to give money as a simple loan, one that can just be repaid afterwards without rent. Whoever would not jump at this opportunity? Although I knew this was prohibited, but if we are afraid we cannot go ahead. Eventually I took this chance, I took the trawlers and I operated in Indonesia. I thought it would be hard to do this but I believed I could do it. I observed that logging was illegal but it happened. So, what was wrong in trying to work with trawlers that were illegal? I just had no worries at that time and eventually I could bring in 13 trawlers from Malaysia. This happened between 2000 and 2004. The yields were okay. However, after we calculated the income that had gone to the Malaysian traders to whom we brought the fish, we certainly did not have much profit. There were still three vessels left out of 10 that I was given from Tawau. All the vessels were assumed to belong to me. Later, since I felt many prohibitions from the tightened rules, I then changed two vessels into purse seiners. I changed the fishing gear but the vessels and engines remained the same. I took the gear from Nunukan since I thought if I got them from Malaysia and sent it to Berau it would be very difficult. For that reason I assembled the nets (pukat) there in Nunukan instead of in Malaysia. If I would have them made in Malaysia and imported directly into Berau, how would I have managed? Surely, the process would have taken longer as it takes time to make the gear outside Berau and it needs time to deliver them here. (Interview with Haji Nassir (36 years), Sambaliung 24-12-2009.)

The interviews above are parallel with the issues of territorialization and transborder marine resources. Visser and Adhuri (2010) state that the concept of transborder fishery showing the complex interactions of social, economic and political events and actions within particular institutional settings across regional and national boundaries and borders. The life histories of Haji Nassir above show that transborder fish trade between Malaysia and Indonesia enabled access to the rich coastal resources in Berau. It also shows that transborder resource trade is created by political networking between actors in two different countries and across institutions, including the political and administrative changes from centralisation to decentralization government systems. 
FISHERS' PERCEPTIONS OF THEIR FUTURE

This section discusses fishers' perceptions regarding fishery income changes and its causes, and how fishers see fishing as their future livelihood. For that purpose I take the example of how a gill netter in Teluk Semanting sees the changes in fishery:

There are clear differences in annual catches. From one year to the next, the difference is not so evident actually. But if we compare five years ago and today we really see the difference; it was better five years ago. However, for example from 2007 to 2008, the difference in the catch could not be seen as it was only little. When I first went fishing in the 1990s, fish were easy to catch. (Interview with Eswahyudi (24 years), Teluk Semanting, 22-5-2008.)

Fishers in Kasai perceive their fishing income has indeed changed over the last ten years. Most of them (73.2\%) felt the income had decreased. Meanwhile some fishers (15.5\%) remark their income remained stable, while others saw an increased income $(11.3 \%)$. Fishing income went down, especially during the transition and southern seasons when they have a poor catch. A few fishers indicated that they might move out of fishing as their main livelihood, probably to a pond aquaculture-based livelihood.

Fishers in Kasai perceive that the income changes they face are caused by the higher costs of production (53.4\%) due to higher fuel prices in 2008 and higher gear prices. Some other fishers said that income went down due to a decreased catch $(23.3 \%)$ and a lower shrimp price $(23.3 \%)$. Fishers believe that fishing is their future $(70.1 \%)$ as they do not have any other main livelihoods as shown in Table 8 below. However, I got the impression that they actually want to be pond farmers as they perceive it earns better than fishing. However, in Kasai they do not have access to ponds as in this village there is little mangrove forest.

\begin{tabular}{lcccccc}
\hline \multirow{2}{*}{ Type of fisher } & \multicolumn{3}{c}{ Fishing as future livelihood* } & \multirow{2}{*}{ Total } & \multirow{2}{*}{$\%$} \\
\cline { 2 - 4 } & Yes & $\%$ & No & $\%$ & & \\
\hline Trammel netter & 44 & 45.4 & 16 & 16.5 & 60 & 61.9 \\
Mini trawler & 10 & 10.3 & 7 & 7.2 & 17 & 17.5 \\
Longliner & 3 & 3.1 & 1 & 1.0 & 4 & 4.1 \\
Gill netter & 5 & 5.2 & 4 & 4.1 & 9 & 9.3 \\
Crab catcher & 6 & 6.2 & 1 & 1.0 & 7 & 7.2 \\
\hline Total & 68 & 70.1 & 29 & 29.9 & 97 & 100.0 \\
\hline
\end{tabular}

*Pearson Chi-square $=3.099$ (not significant)

Table 8. Perceptions of fishing for future livelihoods of Kasai fishers ( $\mathrm{N}=97)$. 


\section{CONCLUSION}

In this article I have shown that there is no single fishery-based livelihood in the Berau Delta. I have presented the diversity of fishery-based livelihoods according to the five main gear classes as they are distinguished among the fishers in Kasai and Teluk Semanting themselves, and applied in our survey. The everyday life of fishers shows not only that fishing is the main livelihood for coastal people but also that it is embedded in political-economic patronage networks between actors and across institutions as the result of values, interests and knowledge contestations. Fishing practices are influenced by the habitus (Bourdieu 1990) of the Bugis hierarchy that generates the patronage network between the punggawa (boss or trader) and the dependent fishers. Loans are provided by the punggawa who himself depends on the delivery of the produce; thus interdependency characterizes the asymmetrical power relationship between punggawa and fisher.

Livelihood trajectories of different fishers from various classes show that as social actors, whether rich or poor, they have the agency to search for better livelihoods. The patrons usually do not go out at sea, and much of the decision-making is done by the dependent fishers on the boats. Changing fishing gear over a life time, taking a variety of fishing gear into the boat for a trip, dealing with the seasons and having practical knowledge to access good fishing grounds in the rich coastal waters are important strategies developed by the fishers in Berau.

\section{REFERENCES}

Agergaard, Jytte, Niels Fold, and Katherine V. Gough. 2010. "Introduction”, in: Jytte Agergaard, Niels Fold, and Katherine V. Gough (eds) Rural-urban dynamics; Livelihoods, mobility and markets in African and Asian frontiers, pp. 1-22. London and New York: Routledge.

Bernard, Harvey Russell. 2002. Research methods in anthropology; Qualitative and quantitative approaches.Third edition. Oxford: AltaMira Press.

Bourdieu, Pierre. 1990. The logic of practice. Stanford: Stanford University Press.

BPS Berau. 2008. Berau dalam angka 2008. Tanjung Redeb: Badan Pusat Statistik Kabupaten Berau.

BPS Berau. 2011. Berau dalam angka 2011. Tanjung Redeb: Badan Pusat Statistik Kabupaten Berau.

DKP Berau. 1999-2011. Laporan tahunan. Tanjung Redeb: Dinas Perikanan dan Kelautan Kabupaten Berau.

Gunawan, Bambang I. and Leontine E. Visser. 2012. "Permeable boundaries; Outsiders and access to fishing grounds in the Berau marine protected area", Anthropological Forum 22(2): 187-207.

Haan, Arjan de, Karen Brock, and Ngolo Coulibaly. 2002. “Migration, livelihoods and institutions; Contrasting patterns of migration in Mali", in: Arjan de Haan and Ben Rogaly (eds), Labour mobility and rural society, pp. 37-58. London: Frank Cass. 
Hutabarat, Sahala and Stewart M. Evans. 1985. Pengantar oseanografi. Jakarta: UI Press.

Levang, Patrice. 2002. "Mangroves, shrimps, and punggawa; A historical analysis of the development of the Delta Mahakam". Unpublished report to PT Win and Total Fina Elf, Jakarta, Indonesia.

Long, Norman. 2001. Development sociology; Actor perspectives. London and New York: Routledge.

Lowe, Celia. 2003. "The magic of place; Sama at sea, on land, in Sulawesi, Indonesia", Bijdragen tot de Taal-, Land en Volkenkunde 159(1): 109-133.

MMAF. 2006. Statistik perikanan budi daya Indonesia (Indonesian aquaculture statistics) 2005. Jakarta: Departemen Kelautan dan Perikanan.

MMAF. 2009. Statistik kelautan dan perikanan (Marine and fisheries statistics). Jakarta: Kementerian Kelautan dan Perikanan.

MMAF. 2010a. Statistik kelautan dan perikanan (Marine and fisheries statistics) 2008. Jakarta: Kementerian Kelautan dan Perikanan.

MMAF. 2010b. Rencana strategis Kementerian Kelautan dan Perikanan 2010-2014. Jakarta: Kementerian Kelautan dan Perikanan.

MMAF. 2011. Statistik kelautan dan perikanan (Marine and fisheries statistics). Jakarta: Kementerian Kelautan dan Perikanan.

Nontji Anugerah. 2005. Laut Nusantara. Jakarta: Ikrar Mandiri Abadi.

Ontita, Edward G. 2007. Creativity in everyday practice; Resources and livelihoods in Nyamira, Kenya. PhD thesis, Wageningen University.

Pauwelussen, Annet. 2010. "Fishing nets and family ties; An exploration of social resilience in an Indonesian coastal frontier area". Master thesis, Wageningen University.

Pelras, Christian. 1996. The Bugis. Oxford: Blackwell Publishers.

Pelras, Christian. 2000. "Patron-client ties among the Bugis and Makassarese of South Sulawesi”, in: G. Acciaioli, K. van Dijk, and R. Tol (eds), Authority and enterprise among the peoples of South Sulawesi, pp. 15-54. Leiden: KITLV Press. [Verhandelingen 188.]

Poate, C.D. and P. F. Daplyn. 1993. Data for agrarian development. Cambridge: Cambridge University Press.

Schrauwers, Albert. 1999. "It's not economical; The market roots of a moral economy in highland Sulawesi, Indonesia", in: Tania M. Li (ed.), Transforming the Indonesian uplands; Marginality, power and production, pp. 105-130. Amsterdam: Harwood Academic Publishers.

Timmer, Jaap. 2011. “Being seen like the state; Emulations of legal culture in customary labor and land tenur arrangements in East Kalimantan, Indonesia", American Ethnologist 37(4): 703-712.

Wiryawan, Budi, Khazali, and Maurice Knight. 2005. Menuju kawasan konservasi laut Berau Kalimantan Timur; Status sumber daya pesisir dan proses pengembangan KKL. Program bersama Kelautan Berau TNC-WWF-Mitra Pesisir/CRMP II USAID. Jakarta.

Visser, Leontine E. and Dedi S. Adhuri. 2010. “Territorialization re-examined; Transborder marine resources exploitation in Southeast Asia and 
Australia", in: W. de Jong, D. Snelder, and N. Ishikawa (eds), Transborder governance of forests, rivers, and seas, pp. 83-98. London: Earthscan.

Yin, Robert K. 2003. Case study research; Design and methods. London and New Delhi: Sage Publications. 